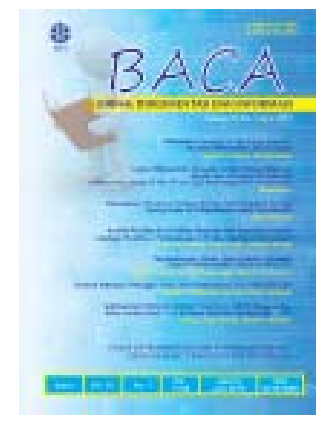

\title{
SHOPPING MALL LIBRARY: KAJIAN TERKINI DI EMPAT NEGARA ASIA TENGGARA
}

\author{
Madiareni Sulaiman ${ }^{1 *}$ \\ ${ }^{1}$ Pusat Dokumentasi dan Informasi Ilmiah LIPI \\ *Korespondensi: punyarenie@gmail.com
}

Diajukan: 9-1-2016; Direview: 4-3-2016; Diterima: 14-3-2016; Direvisi: 2-4-2016

\begin{abstract}
This paper discuss about recent researches with shopping-mall library as the main topic and their management for society. This concept is unique because we view the library as a place for user. It is actually already a familiar thing for user in developed country, like United States, United Kingdom and Australia. But, in some of the Southeast Asian country, it is already applied for the last ten years, especially Indonesia. However, it has slow response in Indonesia because the lack of socialization. Whereas, in the other Southeast Asian country, this kind of library was full supported by government and private company.This paper uses qualitative research with literature study from books, journal articles and web articles. It is delivered with systematic description of recent studies. The study is limited to the Southeast Asia region, especially in Singapore, Malaysia, Thailand and Indonesia. The result of study is that shopping-mall library already applied in some country with different terms, such as Library@Mall in Singapore, myLibrary in Malaysia, Knowledge Park in Thailand and TBM@Mall in Indonesia. It is managed by government and private institution in order to make sustainable development for library management (vision, resources: staffs, collections and facility, and socialization/promotion).
\end{abstract}

\begin{abstract}
ABSTRAK
Kajian ini membahas tentang perpustakaan mal (shopping-mall library) dan penerapannya bagi masyarakat. Konsep perpustakaan mal ini sebenarnya sudah tidak asing lagi bagi pengguna luar negeri, seperti Amerika, Inggris, dan Australia. Beberapa negara di Asia Tenggara juga sudah menerapkannya sejak sepuluh tahun terakhir, termasuk Indonesia. Namun, pengembangan perpustakaan mal di Indonesia masih terhitung lambat karena masih minimnya informasi yang diterima pengguna mengenai keberadaan perpustakaan di mal. Sementara itu, di Asia Tenggara lainnya perpustakaan mal mendapat perhatian besar dan dukungan dari pemerintah yang bekerja sama dengan pihak swasta. Hal inilah yang menjadi latar belakang dilakukannya kajian. Pendekatan yang digunakan kajian ini bersifat kualitatif dengan metode pengumpulan data melalui studi literatur, seperti buku, artikel jurnal, ataupun artikel situs web. Hasil kajian ini disampaikan secara deskriptif sistematis untuk memudahkan penyampaian konsep perpustakaan mal dari studi ilmiah terkini. Studi dibatasi pada wilayah Asia Tenggara, khususnya Negara Singapura, Malaysia, Thailand, dan Indonesia. Hasil kajian menunjukkan bahwa perpustakaan mal sudah diterapkan di beberapa negara Asia tenggara dengan istilah yang berbeda-beda, seperti Library@Mall di Singapura, myLibrary di Malaysia, Knowledge Park di Thailand, dan TBM@Mall di Indonesia. Perpustakaan mal ini dikelola dengan baik oleh pemerintah maupun swasta sehingga pengembangannya dapat berkelanjutan, baik dari aspek manajemen, visi, sumber daya (staf, koleksi dan fasilitas), sosialisasi, maupun promosi kepada masyarakat.
\end{abstract}

Keywords: Shopping mall library; Public library; Southeast Asia 


\section{PENDAHULUAN}

Masyarakat pada generasi saat ini cenderung menghabiskan waktu luang dengan mengakses informasi dari berbagai sumber, khususnya melalui gadget. Perkembangan teknologi memungkinkan masyarakat mempunyai kebutuhan informasi yang sangat tinggi bisa lebih mudah memperolehnya dengan memanfaatkan berbagai metode jika dibandingkan beberapa dekade lalu. Akses informasi pada mulanya hanya bersumber pada media tercetak dan audio-visual. Namun, saat ini akses informasi dapat dilakukan dengan satu kali sentuhan, dimanapun, dan kapanpun. Hal ini secara tidak langsung mencerminkan betapa tingginya minat masyarakat terhadap akses informasi.

Masyarakat modern yang berada di perkotaan, pada umumnya menggunakan waktu luang di tempat keramaian, seperti pusat perbelanjaan sebagai salah satu bentuk rekreasi. Hal yang pertama kali terpikirkan jika mendengar kata "mal” adalah tempat segala kegiatan ataupun pemerolehan suatu barang yang memerlukan biaya (transaksi), seperti baju, keperluan rumah tangga, ataupun makan siang bersama kolega. Di beberapa tempat, khususnya di wilayah Asia Tenggara, konsep pikir masyarakat terhadap mal telah berubah. Jika mengunjungi mal dengan konsep perpustakaan, masyarakat tersebut akan berpikir buku apa yang akan dipinjam untuk selanjutnya.

Pusat perbelanjaan atau yang biasa disebut "mal”, merupakan suatu kata benda yang didefinisikan sebagai gedung atau kelompok gedung yang berisi berbagai jenis toko dengan dihubungkan oleh lorong/ jalan penghubung (Pusat Bahasa Depdiknas, 2008). Berdasarkan hasil riset yang dilakukan Katz \& Rice (2009) terkait Consumer Survey Indonesia (CSI) pada bulan Februari 2010, toko buku menjadi urutan konter yang paling banyak dikunjungi (33\%). Dalam hal ini, penilaian tujuan kunjungan ke toko buku lebih kepada tempat untuk membaca dan membuka-buka informasi sambil menunggu sesuatu atau seseorang. Dengan konsep tersebut, mal merupakan suatu ruang publik yang dibuat untuk berbagai kepentingan, termasuk perpustakaan. Jika melihat perpustakaan sebagai tempat (library as place), maka ide terhadap perpustakaan tersebut akan mendekati konsep kenyamanan bagi pengguna perpustakaan. Perpustakaan yang diharapkan saat ini adalah tempat yang dapat menghimpun individu maupun komunitas untuk berkreasi. Salah satu tantangan yang muncul adalah menentukan lokasi yang tepat untuk menempatkan perpustakaan.

Berdasarkan hal tersebut, kajian ini fokus membahas perpustakaan mal di Asia Tenggara sebagai bahan perbandingan, serta evaluasi pengelolaan perpustakaan mal di Indonesia. Wilayah Asia Tenggara yang menjadi objek kajian adalah Singapura, Malaysia, Thailand, dan Indonesia. Singapura telah merintis perpustakaan di mal sejak tahun 1994, yang disampaikan pada program Library 2000 (Balamurugan, 2005) dan Library 2010 (Tan \& Foo, 2006). Malaysia mulai merintisnya sejak tahun 2012. Thailand sejak tahun 2005 dan Indonesia mulai tertarik membangun perpustakaan mal sejak tahun 2010. Pembangunan perpustakaan mal di Indonesia diawali dengan program pembangunan Taman Bacaan Masyarakat (TBM) di mal yang tersebar di beberapa kota besar, seperti Jakarta, Bandung, Surabaya, dan Makassar (Redaksi Dunia Perpustakaan, 2010).

\section{METODE}

Pendekatan dalam kajian ini bersifat kualitatif dengan metode pengumpulan data melalui studi literatur, yang bersumber dari buku, artikel jurnal, atau artikel berita formal di situs web. Hasil kajian 
disampaikan secara deskriptif sistematis guna memudahkan penyampaian konsep perpustakaan mal dari studi ilmiah. Studi dibatasi pada wilayah Asia Tenggara, khususnya Singapura, Malaysia, Thailand, dan Indonesia. Analisis kajian didasarkan kepada studi empiris tahun 2005-2012 yang membahas topik shopping-mall library di empat Negara tersebut. Kajian ini tidak membahas bagaimana informasi tersebut diproduksi, diterbitkan, dan dibuat akses terhadap terbitannya.

\section{HASIL DAN PEMBAHASAN}

Shopping-mall library menjadi satu dari berbagai perpustakaan yang dikategorikan unik dan dekat dengan pengguna karena selain perpustakaan komunitas juga perpustakaan dengan koleksi khusus. Singapura hingga saat ini memiliki sembilan shopping-mall library yang ditempatkan pada mal di daerah utama dengan memfokuskan anak-anak dan remaja sebagai populasi pengguna. Perpustakaan ini bersifat modern dengan luas sekitar 16.000 kaki $\left(1500 \mathrm{~m}^{2}\right)$, dilengkapi koleksi yang lebih banyak berbentuk audio-visual dan majalah populer. Daya tarik shopping-mall library ini tidak dapat dibantahkan karena terbukti bahwa kegiatan sirkulasi dan jumlah pengunjung mencapai $40 \%$ walaupun luas perpustakaan mal ini 20\% lebih kecil jika dibandingkan dengan perpustakaan umum (Matthews, 2009).

Shopping-mall library juga menjadi salah satu model perpustakaan alternatif. Model ini didefinisikan sebagai fasilitas layanan lengkap dengan minim staf. Koleksi dan teknologi yang dimiliki perpustakaan alternatif ini disesuaikan dengan wilayah/area yang dilayani (demografi pengguna) serta dilengkapi berbagai program khusus. Ukuran perpustakaan alternatif umumnya berkisar 3000 kaki $\left(280 \mathrm{~m}^{2}\right.$ ). Model ini diharapkan dapat melayani pengguna khusus, seperti anak-anak hingga dewasa, dengan koleksi yang bersifat populer serta ruang baca yang nyaman (Godfrey’s Associates Inc., 2010).

Apabila melihat aspek aksesibilitas, penempatan atau lokasi perpustakaan harus dekat dengan pengguna. Hal ini disesuaikan dengan kebutuhan informasi pengguna. Park Sung Jae (2011) mengatakan bahwa didapatkan bahwa jarak antara lokasi penduduk dengan perpustakaan umum dapat diukur menggunakan Thiessen polygon (geographic information systems). Pengukuran berdasarkan data demografi pun dilakukan dan didapatkan hasil perlunya mempertimbangkan lokasi perpustakaan dengan keluarga yang memiliki anak serta yang masih berada pada tingkat pendidikan dasar. Untuk meningkatkan aksesibilitas terhadap perpustakaan umum, direkomendasikan kepada pustakawan untuk menentukan secara tepat wilayah layanan perpustakaan untuk mengembangkan program untuk komunitas serta mengevaluasi kebutuhan pengguna.

Manfaat dari perpustakaan mal adalah membantu dalam pembangunan komunitas dengan menarik pengguna (pelanggan) untuk berkunjung ke perpustakaan. Pengguna dalam konteks ini dapat membantu perpustakaan untuk menawarkan berbagai program kegiatan dengan pendekatan "seperti ritel” dan membangkitkan pemahaman terhadap konsep perpustakaan modern. Pada beberapa kasus, perpustakaan dengan ruang lebih kecil akan lebih efektif dalam hal biaya maupun pengelolaannya dalam melayani pengguna. Selain itu, pengguna yang datang ke perpustakaan mal dapat sementara waktu menjauhkan diri dari keramaian dan hiruk pikuk dunia ritel (Blankinship, 2005).

\subsection{Perpustakaan Mal Wilayah Singapura}

National Library Board (NLB) Singapura berkolaborasi dengan pemerintah, industri, dan 
komunitas bersama perpustakaan lainnya untuk merealisasikan visi mereka yang disampaikan dalam program Library 2000 dan Library 2010. Kerjasama ini mulai dilaksanakan sejak tahun 1994 (Library 2000) di mana terdapat pengembangan inovasi pada manajemen dan layanan perpustakaan, program, dan promosi serta bangunan dan jaringan terhadap konten yang dimiliki perpustakaan. Pada tahun 2005, visi program Library 2010 berlanjut dalam rangka menjadi penyedia utama sumber pengetahuan bagi warga Singapura (Tan \& Foo, 2006).

\subsection{Perpustakaan Mal Wilayah Malaysia}

Perpustakaan mal di Malaysia, yaitu Library@Suria didirikan oleh Sabah State Library bekerjasama dengan National Library Board of Singapore pada tahun 2012. Selanjutnya, myLibrary didirikan di Sutera Mall, kerja sama secara corporate social responsibility (CSR) dari pihak swasta dengan pemerintah, yaitu Tanah Sutera Devt. Sdn. Bhd. and Cybarian Ventures Pte Ltd. Perpustakaan mal di Malaysia menjadi contoh bentuk kerja sama hasil CSR yang berupaya untuk memajukan budaya baca bagi masyarakat Malaysia.

\subsection{Perpustakaan Mal Wilayah Thailand}

Pemerintah Thailand sudah mulai menggalakkan promosi membaca sejak tahun 2009 dan ditanggapi positif oleh masyarakat. Hal ini dibuktikan dengan adanya program pemerintah, yaitu menjadikan program satu dekade membaca sebagai agenda nasional dari tahun 2009-2018. Kebijakan ini membangkitkan semangat perpustakaan umum untuk berkembang secara kreatif dan inovatif. Pada tahun 2013, UNESCO menetapkan Bangkok sebagai World Book Capital 2013 sehingga promosi membaca kepada masyarakat semakin meningkat. Pada 24 Januari 2005, Thailand Knowledge Park (TK Park) dibentuk dengan konsep percobaan untuk merespon masalah kegiatan membaca di perpustakaan sebagai bentuk learning society. TK Park yang bertempat di Central World ini dengan dukungan pemerintah berkembang menjadi living library dalam bentuk taman pengetahuan dan sangat ditanggapi positif oleh masyarakat.

\subsection{Perpustakaan Mal Wilayah Indonesia}

Dalam rangka meningkatkan minat baca masyarakat di Indonesia, pemerintah mendirikan pusat-pusat baca, seperti Taman Bacaan Masyarakat (TBM). Program ini sebenarnya telah dirintis oleh Kementerian Pendidikan dan Kebudayaan sejak tahun 1950-an dengan program kegiatan Taman Pustaka Rakyat (TPR) yang kemudian diperbarui menjadi TBM pada tahun 1992/1993. Tujuan program ini adalah mewujudkan masyarakat gemar belajar (learning society) dengan terlebih dahulu menjadikan masyarakat gemar membaca (reading society) (Rachmiati, 2011).

TBM adalah lembaga yang menyediakan berbagai jenis bahan belajar yang dibutuhkan oleh masyarakat (Depdiknas, 2008 dalam Rachmiati, 2011). Sementara itu, sesuai dengan Pedoman Penyelenggaraan Taman Bacaan Masyarakat (Direktorat Pendidikan Masyarakat, 2011: 9), definisi TBM merupakan sebuah tempat yang didirikan dan dikelola oleh masyarakat maupun pemerintah untuk memberikan layanan bahan bacaan bagi masyarakat sebagai sarana pembelajaran seumur hidup untuk meningkatkan kualitas hidup masyarakat. Oleh karena itu, dapat diperoleh pemahaman bahwa TBM merupakan suatu wadah bagi masyarakat informasi (information society) untuk 
melakukan pembelajaran seumur hidup dalam menyalurkan kegemaran akan kegiatan membaca. Untuk itu, lokasi TBM yang memenuhi unsur kemudahan jangkauan masyarakat luas, salah satunya adalah pusat perbelanjaan atau mal, yang disebut dengan istilah TBM@Mall. Program ini menjadi target Kementerian Pendidikan Nasional (Kemdiknas) tahun 2010 dengan mendirikan 23 TBM@Mall yang tersebar di beberapa kota besar di Indonesia, yaitu Jakarta, Bandung, Surabaya, Makassar, dan lain-lain.

Pada penelitian yang mengangkat mengenai evaluasi terhadap layanan TBM@Mall di Jakarta diperoleh hasil bahwa koleksi yang dimiliki cukup membantu pengguna serta layanan yang diberikan dinilai baik oleh pengguna terutama mahasiswa (Ariowibowo, 2012 dan Humaisa, 2013). TBM@Mall merupakan sebuah taman bacaan untuk masyarakat yang mirip perpustakaan, tetapi memiliki konsep lebih dengan mendatangkan suasana rekreatif (Rachmiati, 2011).

Sejauh ini, TBM yang ada di lingkungan masyarakat belum dimanfaatkan secara maksimal dan optimal karena hanya digunakan untuk membaca dan meminjam buku saja (42\%). Hal ini disebabkan karena pengelolaan sebagian TBM kurang maksimal dan motivasi masyarakat untuk berkunjung pun berkurang (20 - 30 orang/hari). Oleh karena itu, kegiatan pengelolaan TBM sebagai penyelenggara pendidikan non-formal perlu mengupayakan penyampaian informasi dalam manajemen organisasi dan peningkatan kompetensi pengelola TBM (Nugroho \& Maureen, 2012). Hal ini perlu diperhatikan karena telah disampaikan dalam Petunjuk Tenis Pengajuan dan Pengelolaan Bantuan Taman Bacaan Masyarakat Ruang Publik (2012) bahwa kriteria layanan TBM@Mall yang inovatif dan kreatif adalah perlu mengenali pengguna dan berbagai kebutuhannya, mensosialisasikan TBM kepada masyarakat, membentuk kelompok sasaran, memfasilitasi layanan bimbingan kemampuan membaca serta menyelenggarakan kegiatan kompetitif seperti perlombaan maupun diskusi untuk meningkatkan kebermanfaatan TBM bagi masyarakat.

Adapun kajian terkini yang membahas shopping-mall library di Asia Tenggara telah dirangkum dalam Tabel 1.

Tabel 1. Shopping-Mall Library di Asia Tenggara berdasarkan The Customer-Focused Library (Matthews, 2009)

\begin{tabular}{|c|c|c|c|c|}
\hline $\begin{array}{l}\text { Shopping-Mall } \\
\text { Library } \\
\text { Costumer- } \\
\text { Focused Library }\end{array}$ & $\begin{array}{c}\text { Singapura } \\
\text { (Library@Orchard) } \\
\text { Orchard }\end{array}$ & $\begin{array}{c}\text { Malaysia } \\
\text { (Library@Suria) } \\
\text { Kinabalu }\end{array}$ & $\begin{array}{c}\text { Thailand } \\
\text { (TK Park) } \\
\text { Pathum Wan }\end{array}$ & $\begin{array}{c}\text { Indonesia } \\
\text { (TBM@Mall) } \\
\text { Blok M }\end{array}$ \\
\hline $\begin{array}{l}\text { Release date / } \\
\text { Program } \\
\text { administrator }\end{array}$ & $\begin{array}{l}\text { October } 21^{\text {st }}, 1999 \\
\text { by Minister of } \\
\text { Information and } \\
\text { the Arts (renovated } \\
\text { and opened at } \\
\text { October } 23^{\text {rd }}, 2014 \\
\text { by Minister for } \\
\text { Communications } \\
\text { and Information) }\end{array}$ & $\begin{array}{l}\text { February } 1^{\text {st }}, 2012 \\
\text { by Sabah State } \\
\text { Library }\end{array}$ & $\begin{array}{l}\text { January } 24^{\text {th }}, 2549 / \\
2006 \text { or June } 18^{\text {th }} \text {, } \\
2547 / 2004 \text { by } \\
\text { Ministry of } \\
\text { Education and } \\
\text { Office of } \\
\text { Knowledge } \\
\text { Management and } \\
\text { Organizational } \\
\text { Development }\end{array}$ & $\begin{array}{l}\text { Mei } 2^{\text {nd }}, 2010 \text { by Ministry } \\
\text { of Education and publice } \\
\text { figure like Dina Mariana, } \\
\text { Andi F. Noya, Rieke Dyah } \\
\text { Pitaloka and Dewi Hughes } \\
\text { (with @American) }\end{array}$ \\
\hline $\begin{array}{l}\text { Vision and } \\
\text { Mission }\end{array}$ & $\begin{array}{l}\text { Bring library to the } \\
\text { people }\end{array}$ & $\begin{array}{l}\text { - A vibrant info- } \\
\text { hub space for } \\
\text { reading and } \\
\text { learning. } \\
\text { - To bring to the } \\
\text { people, reliable }\end{array}$ & $\begin{array}{l}\text { To develop } \\
\text { knowledge, } \\
\text { replicate the } \\
\text { prototype } \\
\text { Knowledge Park } \\
\text { and promote the }\end{array}$ & $\begin{array}{l}\text { - } \quad \text { To increase reading } \\
\text { interest } \\
\text { - } \quad \text { To literate the society } \\
\text { - } \quad \text { To make TBM@Mall } \\
\text { as forum for } \\
\text { community learning }\end{array}$ \\
\hline
\end{tabular}




\begin{tabular}{|c|c|c|c|c|}
\hline & & $\begin{array}{l}\text { information and } \\
\text { resources that } \\
\text { will enhance the } \\
\text { quality of their } \\
\text { lives with } \\
\text { dedicated staff, } \\
\text { useful and } \\
\text { current } \\
\text { contents, } \\
\text { comprehensive } \\
\text { programmes, } \\
\text { service and } \\
\text { cutting-edge } \\
\text { technology. }\end{array}$ & $\begin{array}{l}\text { living libraries } \\
\text { TK Park has } \\
\text { established } \\
\text { different types } \\
\text { of "living } \\
\text { libraries” in } \\
\text { order to support } \\
\text { creative public } \\
\text { learning and } \\
\text { reading habit } \\
\text { according to the } \\
\text { local needs } \\
\text { across Thailand } \\
\text { To develop } \\
\text { prototype } \\
\text { online learning } \\
\text { community or } \\
\text { Digital TK at } \\
\text { www.tkpark.or.th } \\
\text { To develop } \\
\text { prototype } \\
\text { activities for } \\
\text { creative public } \\
\text { learning } \\
\text { To help create } \\
\text { learning society } \\
\text { in Thailand }\end{array}$ & \\
\hline $\begin{array}{l}\text { It's All About the } \\
\text { Customer }\end{array}$ & $\begin{array}{l}\text { User: who are } \\
\text { interested in design, } \\
\text { lifestyle and applied } \\
\text { arts. }\end{array}$ & $\begin{array}{l}\text { User: communities, } \\
\text { groups and all ages }\end{array}$ & $\begin{array}{l}\text { User: children, youth, } \\
\text { adult } \\
\text { For master learning } \\
\text { center that promotes } \\
\text { reading and learning } \\
\text { (live long learning) } \\
\text { to developing skills } \\
\text { of thinking which } \\
\text { will lead to creative } \\
\text { learning society for } \\
\text { children and youth }\end{array}$ & $\begin{array}{l}\text { User: children, youth, } \\
\text { adult }\end{array}$ \\
\hline Library as Place . & $\begin{array}{l}\text { - Library@Orchard } \\
\text { at Orchard Road. } \\
\text { (1700 sq m.). } \\
\text { - Library@Esplanade } \\
\text { at Esplanade Mall. } \\
\text { (2308 sq m). } \\
\text { September 12 }{ }^{\text {th }} \\
\text { 2002 by Minister } \\
\text { of State for } \\
\text { Transpor and } \\
\text { Information, } \\
\text { Communication } \\
\text { and the Arts. } \\
\text { Musics, dance, } \\
\text { theatre and film } \\
\text { collection } \\
\text { (110.000 v.). } \\
\text { Varying level users } \\
\text { interest in the } \\
\text { performance art. } \\
\text { Library@ } \\
\text { Chinatown at } \\
\text { Chinatown Point } \\
\text { Mall. (1000 sq m.). } \\
\text { January 31 }{ }^{\text {st }} \text { 2013. } \\
\text { By Minister of } \\
\text { Culture, } \\
\text { Community and } \\
\text { Youth. (44.000 v.). } \\
\text { For arts and }\end{array}$ & $\begin{array}{l}\text { - } \text { Library@Suria at } \\
\text { Suria Sabah } \\
\text { Shopping Mall, } \\
\text { Kinabalu by Sabah } \\
\text { State Library. } \\
\text { (6000 sq ft). } \\
\text { - } \text { MyLibrary - } \\
\text { Vibrant info-hub } \\
\text { space for reading } \\
\text { and learning at } \\
\text { Sutera Mall4 } \\
\text { floor (CSR) by } \\
\text { Tanah Sutera Devt. } \\
\text { Sdn. Bhd. and } \\
\text { Cybarian Ventures } \\
\text { Pte Ltd. }\end{array}$ & $\begin{array}{l}\text { TK Park - Live } \\
\text { library at Central } \\
\text { World } 8^{\text {th }} \text { floor. } \\
\text { (4000 sq m.) } \\
\text { Inspired by Bpi Public } \\
\text { Information Library } \\
\text { (Bibliotheuque } \\
\text { publique } \\
\text { d’information); } \\
\text { Pompidou center, } \\
\text { France; Library } \\
\text { Learning } \\
\text { Information, UK; } \\
\text { Sendai Mediatheque, } \\
\text { Japan; Jurong } \\
\text { Regional Library and } \\
\text { Library@Orchard, } \\
\text { Singapore }\end{array}$ & 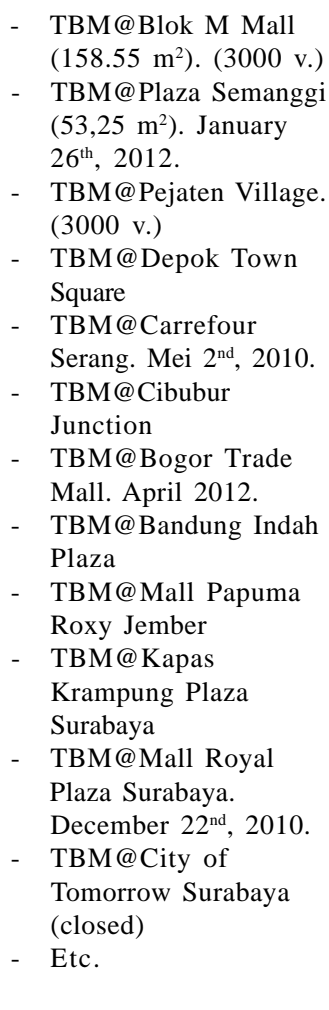 \\
\hline
\end{tabular}




\begin{tabular}{|c|c|c|c|c|}
\hline & 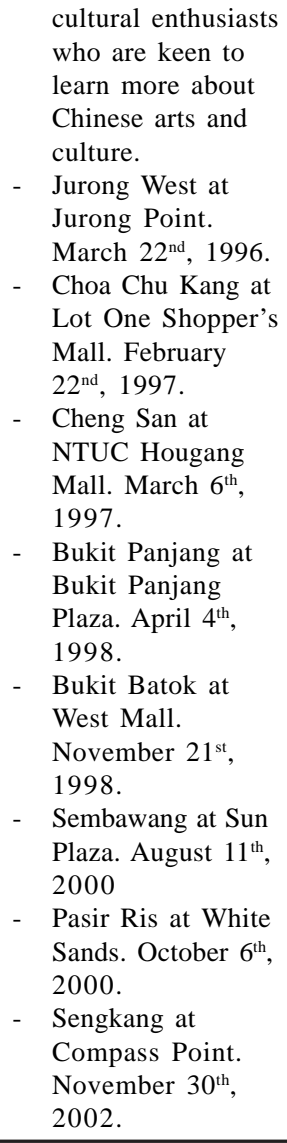 & & & \\
\hline $\begin{array}{l}\text { The Library } \\
\text { Collection }\end{array}$ & $\begin{array}{l}\text { - Fiction and non- } \\
\text { fiction titles, } \\
\text { magazines and } \\
\text { audio-visual } \\
\text { materials } \\
\text { - } \text { eNewspapers, } \\
\text { eBooks and } \\
\text { eMagazines } \\
\text { - } 100.000 \mathrm{v} \text {. } \\
\text { collection }\end{array}$ & $\begin{array}{ll}\text { - } & \text { Reference } \\
\text { - } & \text { Multimedia } \\
\text { - } & 30.000 \text { general } \\
& \text { collections }\end{array}$ & $\begin{array}{ll}\text { - } & \text { Books } \\
\text { - } & \text { Multimedia } \\
\text { - } & 120.000 \text { books } \\
& \text { with } \pm 1.360 .434 \\
& \text { loan collection in } \\
& 8 \text { years }\end{array}$ & 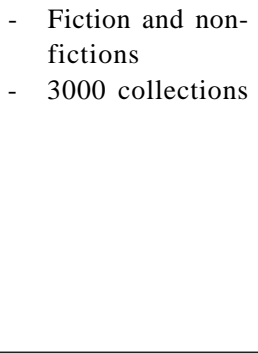 \\
\hline Library Services & $\begin{array}{ll}\text { - } & \text { Digital library } \\
\text { guides } \\
\text { - } & \text { Monthly resident- } \\
\text { maker sessions } \\
\text { - } & \text { Quick reads } \\
& \text { stations } \\
\text { - } & \text { Talks and } \\
\text { - } & \text { Exorkshops } \\
\text { display }\end{array}$ & $\begin{array}{ll}\text { - } & \text { Reference and } \\
\text { information } \\
\text { services } \\
\text { - } & \text { Basic lending } \\
& \text { library services } \\
\text { - } & \text { Library services } \\
\text { - } & \text { Multi-media } \\
& \text { services } \\
\text { - } & \text { Adult member } \\
& \text { services } \\
\text { - } & \text { Youths member } \\
& \text { services } \\
\text { - } & \text { Children’s services }\end{array}$ & - & - \\
\hline $\begin{array}{l}\text { Information } \\
\text { Technology }\end{array}$ & $\begin{array}{l}\text { Bookdrop } \\
\text { www.nlb.gov.sg }\end{array}$ & $\begin{array}{l}\text { www.ssl.sabah.gov.my } \\
\text { www.mylibrary.my }\end{array}$ & www.tkpark.or.th & - \\
\hline Innovation & $\begin{array}{l}\text { - Program zones: } \\
\text { make, imagine } \\
\text { this, imagine that } \\
\text { - "Village" or special } \\
\text { room for music, } \\
\text { dance, theatre and } \\
\text { film. }\end{array}$ & - & $\begin{array}{ll}\text { - } & \text { Quiet Room } \\
\text { - } & \text { Music Room } \\
\text { - } & \text { TK Birth } \\
\text { - } & \text { Knowledge park } \\
& \text { at proviencial level } \\
\text { - } & \text { Living library at } \\
& \text { School }\end{array}$ & - \\
\hline
\end{tabular}


Release date/Program administrator. Shopping-mall library di Singapura didasarkan pada rintisan program dengan konsep perpustakaan “Totally DIY: Do-it-yourself” yang dibentuk pada tahun 1995. Hal ini tercetus karena NLB Singapura ingin memperkenalkan jenis layanan perpustakaan baru yang fokus pada rekreasi, namun terkendala oleh lamanya waktu layanan karena masih bersifat manual. Oleh sebab itu, pada tahun 1998 Singapura mengadopsi sistem otomasi perpustakaan berbasis RFID dan layanan mandiri (self-service) yang sejalan dengan konsep “Totally DIY: Do-it-yourself” tersebut. Untuk efektivitas anggaran maupun manajemen, Layanan mandiri ini banyak diterapkan pada shopping-mall library di Singapura untuk mengefektifkan anggaran dan manajemen (Ngian Lek Choh, 2003). Pada tanggal 21 Oktober 1999, dibentuklah shopping-mall library di Orchard dengan nama “Library@Orchard” oleh Minister of Information and the Arts yang membawahi langsung National Library Board Singapura sesuai dengan rekomendasi program Library 2000 (Ngian Lek Choh, 1997). Sementara itu, shopping-mall library di Malaysia, yaitu Library@Suria didirikan oleh Sabah State Library dan bekerja sama dengan National Library Board of Singapore pada tahun 2012. Konsep di perpustakaan ini pun berkembang seiring inovasi dalam pemenuhan kebutuhan pengguna perpustakaan, yang hal ini didukung oleh program CSR dari beberapa perusahaan di Malaysia (Badri, 2011). TK-Park didirikan pada tanggal 24 Juni 2006/2549 oleh Ministry of Education dan Office of Knowledge Management and Organizational Development. Adapun TBM@Mall dicetuskan oleh Kementerian Pendidikan dan Kebudayaan RI pada tanggal 2 Mei 2010 bekerja sama dengan public figure, seperti Dina Mariana, Andi F. Noya, Rieke Dyah Pitaloka, dan Dewi Hughes bersama@America.

Vision and Mission. Visi dan misi suatu lembaga merupakan dasar dalam melaksanakan kegiatan dan mencapai tujuan dari lembaga tersebut. Perpustakaan mal di Singapura mencetuskan konsep "bring library to the people" sebagai bentuk promosi budaya membaca dan pembelajaran, serta peningkatan aksesibilitas masyarakat. Di Malaysia, seiring dengan maraknya budaya baca pada komunitas masyarakat, Sutera Mall Library mengeluarkan konsep "vibrant info-hub space for reading and learning”, yaitu semua informasi dan layanan perpustakaan ini dapat diakses oleh semua orang. Sama halnya di Thailand, pembentukan TK Park dilakukan atas dasar usaha untuk mengembangkan ilmu pengetahuan secara menyeluruh pada masyarakat Thailand, pembentukan prototipe online serta kegiatan kreatif yang membantu membentuk gaya "masyarakat pembelajar" di Thailand. Indonesia juga mendukung penuh program seperti ini dengan mendirikan TBM@Mall yang memiliki tujuan untuk meningkatkan minat baca dan literasi masyarakat serta membuat forum komunitas pembelajar di Indonesia.

It's All About the Customer. Fokus penting dari suatu organisasi adalah penggunanya. Perpustakaan tentunya juga akan selalu menyediakan layanan kepada pengguna perpustakaan. Pengembangan perpustakaan perlu dilakukan dengan mempertimbangan aspek perencanaan yang disesuaikan dengan kebutuhan layanan maupun fasilitas bagi pengguna. Gambar 1 menampilkan bentuk identifikasi terkait latar belakang seseorang menggunakan perpustakaan yang berdampak pada kebiasaan membaca dan frekuensi kunjungan ke perpustakaan. Perpustakaan mal mengadopsi segmentasi ini dengan membuat gaya perpustakaan yang unik. Seperti di Singapura, mengumpulkan 
data survei dan menghasilkan jenis karakteristik pengguna yang didasarkan pada perbedaan gaya hidup serta gaya belajar (Matthews, 2009). Dari survei terhadap gaya hidup tersebut, National Library di Singapura mendefinisikan pengguna perpustakaan mal sebagai individu yang tertarik pada seni desain, lifestyle, serta seni terapan. Di Malaysia, memfokuskan pengguna perpustakaan lebih umum, yaitu pada komunitas, kelompok, dan semua kalangan umur. Sama halnya di Thailand dan di Indonesia, konsep perpustakaan di mal ditujukan untuk semua kalangan umur, baik anakanak, remaja maupun dewasa. Hal ini dilakukan sebagai bentuk promosi pembelajaran seumur hidup dan pengembangan kemampuan berpikir kreatif di lingkungan masyarakat.

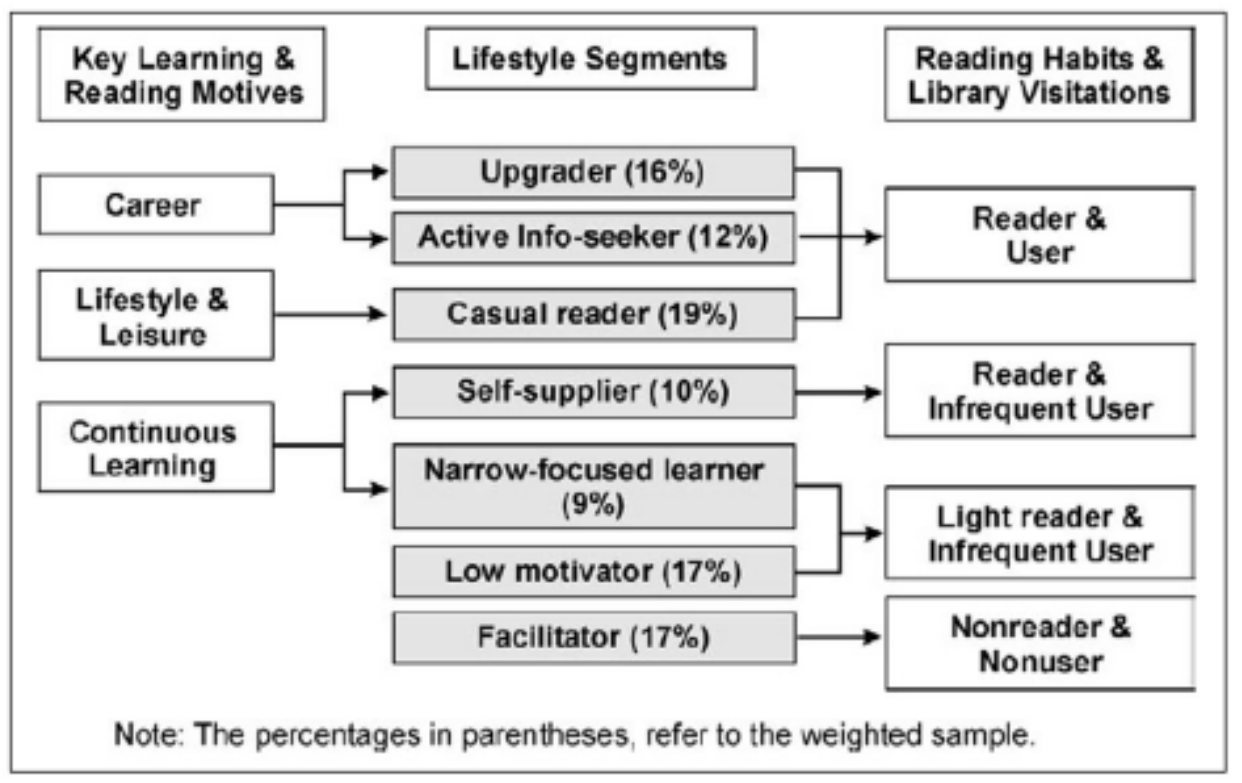

Gambar 1. Summary findings of the seven segments (Matthews, 2009)

Library as Place. Perpustakaan umum dibangun dengan prinsip melayani masyarakat pengguna secara keseluruhan. Opsi lain yang terkait dengan jenis perpustakaan umum adalah perpustakaan yang fokus pada keunikan atau populasi/komunitas. Opsi ini didesain khusus untuk memenuhi kebutuhan populasi dengan segmentasi yang berbeda. Gambar 2 menunjukkan komponen library experience dan menghasilkan segmentasi kebutuhan setiap karakter pengguna perpustakaan serta cara memenuhi kebutuhan tersebut. National Library Board di Singapura bertanggung jawab terhadap beroperasinya perpustakaan umum, perpustakaan komunitas, perpustakaan pemerintah, dan perpustakaan universitas. Konsep outside-in menjadi pelopor terbentuknya program Library 2000 dan Library 2010. Perpustakaan sebagai tempat ini memfokuskan pada layanan yang memberikan kenyamanan, mudah diakses, mudah didapat, dan bermanfaat. Peningkatan perpustakaan dilakukan dengan pengembangan konten koleksi, konsep layanan, pengguna perpustakaan, dan infrastruktur.

Di Singapura terdapat sekitar 11 perpustakaan mal yang dibangun untuk mendukung library as place ini. Konsepnya bermacam-macam, seperti Library@Esplanade yang berfokus pada berbagai tingkatan dan jenis koleksi seni; Library@Chinatown yang berfokus pada seni dan kebudayaan Cina; dan perpustakaan mal di berbagai daerah lainnya di Singapura. Malaysia 
mengusung konsep MyLibrary yang membuat perpustakaan sebagai tempat membaca dan belajar bagi semua kalangan. TK-Park bertempat di Central World dibuat dengan desain dan sistem modern sehingga membuat pengguna perpustakaan, mulai dari anak-anak hingga dewasa, betah menghabiskan waktu untuk belajar dan membaca. Konsep di TK-Park terinspirasi dari gabungan beberapa desain perpustakaan, seperti Bpi Public Information Library di Prancis, Library Learning Center di UK, Sendai Mediatheque di Jepang, Jurong Regional Library, dan Library@Orchard di Singapura. Di Indonesia, perpustakaan di mal dikenal dengan sebutan TBM@Mall. Sejak tahun 2010, program TBM@Mall dikembangkan oleh komunitas bekerja sama dengan pemerintah untuk meningkatkan literasi dan minat baca masyarakat. TBM@Mall berada di kota-kota besar, seperti Jakarta. Bandung. Surabava. dan Makassar.

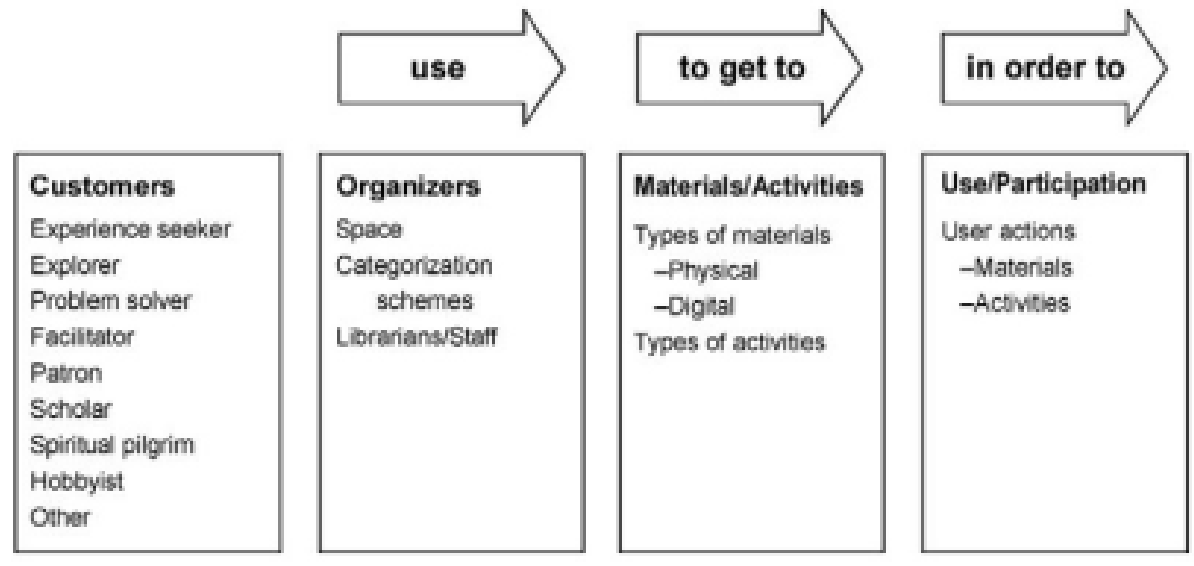

Gambar 2. Komponen library experience (Matthews, 2009)

The Library Collection. Perpustakaan yang berfokus pada pengguna perlu menelusur pengalaman mereka saat mengunjungi dan mengakses koleksi di perpustakaan. Hal ini diperlukan untuk mengetahui kesulitan pengguna saat menelusur atau ragam koleksi yang kurang sesuai dengan kebutuhan. Ezra Schwartz menemukan masalah umum terkait koleksi perpustakaan dan menyebutnya “iceberg problem”. Seperti iceberg atau bongkahan es, koleksi perpustakaan banyak yang tidak terakses oleh pengguna karena masalah penyimpanan di rak dan temu-kembali. Gaya penyimpanan koleksi di rak yang kaku perlu disesuaikan dan lebih inovatif, anatara lain menggunakan metode merchandising dan display organizing (Matthews, 2009). Jenis koleksi perpustakaan mal, baik di Singapura, Malaysia, Thailand, maupun Indonesia hampir sama dalam penyediaannya, namun berbeda dalam segi tampilan. Di Singapura, Malaysia, dan Thailand koleksi perpustakaan beragam untuk semua kalangan dan lebih banyak berbentuk digital yang berjumlah \pm 100.000 eksemplar. Sementara itu, di Indonesia koleksi perpustakaan yang dimiliki masih bersifat umum dan lebih ditujukan untuk kalangan anak-anak dan remaja dengan jumlah \pm 3.000 eksemplar.

Library Services. Pelayanan di perpustakaan perlu menawarkan kenyamanan membaca bagi pengguna. Tantangan saat ini adalah mengembangkan perpustakaan dengan konsep outside-in (fokus pada pengguna), yaitu perlunya mendengarkan pengguna, menanyakan pengguna terkait informasi, selalu siap melayani pengguna dalam berbagai kasus, mengerti kebutuhan pengguna yang beragam, memberi kejutan dan menyenangkan pengguna, diingat/berkesan, responsif, dan membuat brand perpustakaan (Matthews, 2009). Kajian terkini yang mencatat mengenai jenis 
layanan inovatif secara spesifik terkait perpustakaan mal hanya tersedia di Singapura dan Malaysia. Adapun, jenis layanan perpustakaan mal di Thailand dan Indonesia dapat dianggap menggunakan layanan umum, seperti layanan sirkulasi, ruang baca, dan kegiatan umum di perpustakaan mal.

Information Technology. Seiring dengan perkembangan zaman, teknologi informasi dan komunikasi (TIK) berkembang dengan cepat. Adopsi TIK ini segera diterapkan oleh berbagai macam pemberi jasa/layanan kepada masyarakat, termasuk di perpustakaan. Perpustakaan memiliki beragam koleksi yang perlu diolah sedemikian rupa agar dapat dilakukan temu-kembali oleh pengguna. Sistem informasi dan komputer membuat proses temu-kembali ini semakin mudah dan efisien. Sistem ini umumnya disebut Online Public Access Catalogue (OPAC). Perpustakaan mal dengan koleksi yang beragam, walaupun tidak sebanyak perpustakaan umum atau perguruan tinggi, tetap memerlukan OPAC. Katalog online umumnya ditampilkan di website resmi perpustakaan. Katalog online di Singapura dapat diakses melalui website resmi National Library Board of Singapore, sedangkan di Malaysia dapat dilihat di website resmi MyLibrary dan Suria Sabah Library. TK-Park juga memiliki website resmi yang memuat ragam koleksi dan layanan yang dapat dimanfaatkan pengguna perpustakaan. Sayangnya, di Indonesia sampai saat ini belum ada website resmi yang mencantumkan koleksi dan layanan TBM@Mall secara online.

Innovation. Menjadi perpustakaan yang fokus pada pengguna tidak mudah dilakukan jika tidak memiliki visi dan misi perubahan. Implementasi perubahan akan tercapai jika semua unsur organisasi dari atas hingga bawah (top-to-bottom) memiliki tujuan yang sama. Organisasi juga perlu melakukan refleksi untuk mengetahui kelebihan dan kekurangan yang dilihat oleh pengguna, seperti yang ditunjukkan pada Gambar 3. Gambar 3 menunjukkan bahwa pusat dari segala konsep adalah “mendengarkan” pengguna. Jika perpustakaan ingin melakukan inovasi dan uji-coba kegiatan baru bagi pengguna, diperlukan daya kreativitas sesuai tingkatannya. Perpustakaan mal sangat tergantung pada opini penggunanya. Di Singapura dan Thailand, inovasi kegiatan di perpustakaan mal sangat beragam, baik dari segi fasilitas berbasis teknologi terkini maupun event. Sementara itu, inovasi kegiatan perpustakaan mal di Malaysia dan Indonesia terbatas pada program literasi dan peningkatan minat baca kepada masyarakat yang dilakukan oleh beberapa komunitas.

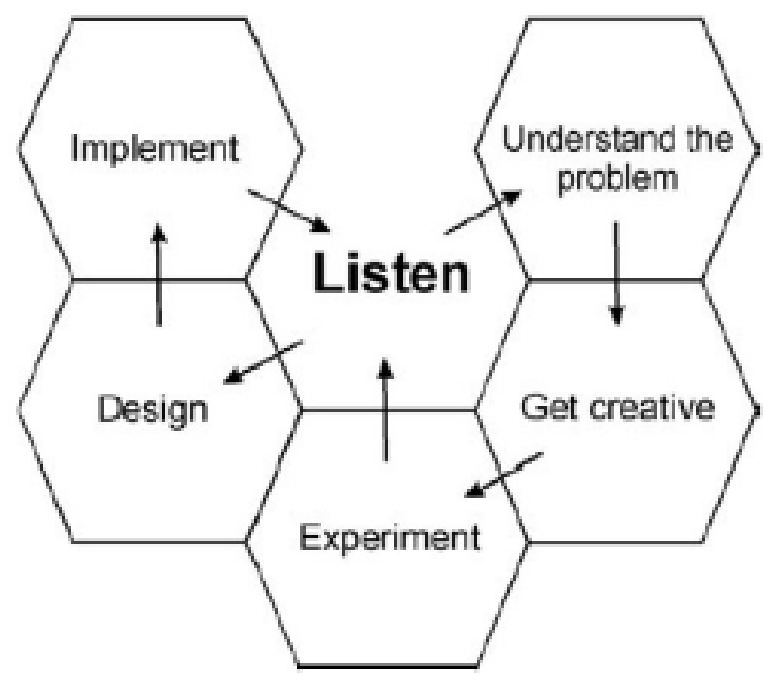

Gambar 3. Siklus inovasi (Matthews, 2009) 


\section{KESIMPULAN}

Berdasarkan pembahasan diketahui bahwa shopping-mall library yang ada di empat negara di Asia Tenggara sudah berjalan dan terus mengembangkan layanannya, walaupun di Indonesia masih memiliki beberapa kendala terkait dukungan sumber daya. Namun, di negara Asia Tenggara lainnya, seperti Singapura, Malaysia, dan Thailand, manajemen perpustakaan mal berjalan dan menjadi daya tarik tersendiri bagi masyarakat di sekitarnya, bahkan menjadi daya tarik wisata. Adapun kesimpulan yang didapatkan dari berbagai hasil studi literatur adalah pengelola perpustakaan mal perlu memperhatikan: 1) perencanaan yang matang dalam mendirikan perpustakaan mal, seperti yang dituangkan dalam Library 2000 dan Library 2010 vision oleh Singapura; 2) bekerja sama dengan pemerintah dan swasta dalam bentuk corporate social responsibility (CSR); 3) fasilitas (desain interior dan perangkat elektronik) disesuaikan dengan kebutuhan pengguna; 4) koleksi dan program perpustakaan disesuaikan dengan kebutuhan pengguna; 5) sumber daya manusia yang berkompeten untuk mengelola perpustakaan mal; 6) aksesibilitas pengguna (untuk costumer-focused library dan disable user); serta 7) sosialisasi dan promosi (bisa berbentuk tujuan wisata, seperti di Thailand).

\section{DAFTAR PUSTAKA}

Ariowibowo, Bagus. 2012. “Penerapan Program TBM Ruang Publik: Studi Kasus di Dua TBM@Mall”. Skripsi. Depok: Universitas Indonesia.

Badri, M. 2011. "Menggali CSR untuk Perpustakaan”. Riau Pos. 2 June (http:// ruangdosen.wordpress.com/2011/06/15/menggali-csr-untuk-perusahaan/, diakses 18 September 2015).

Balamurugan, A. 2005. "Shopping Mall Libraries”. (http://eresources.nlb.gov.sg/infopedia/articles/ SIP_705_2005-01-20.html?s=mall library. diakses 18 September 2015).

Blankinship, D. G. 2005. Let’s Go To The Mall: Thinking Outside The Neighborhood Branch, Libraries In Malls Make For Happy Partnerships And Patrons. Library Journal, 130 (2): 44.

Budiman, Arief. 2012. “Model Pengelolaan TBM@Mall dalam Menumbuhkan Minat Baca Bagi Pengguna”. Skripsi. Bandung: Universitas Pendidikan Indonesia.

Departemen Pendidikan Nasional. 2011. Pedoman Pengelolaan Taman Bacaan Masyarakat (TBM). Jakarta: Direktorat Pendidikan Masyarakat.

Godfrey’s Associates Inc. 2010. Library Facilities Study: Alternative Library Facility Models. 1-18.

Humaisa, Happy. 2013. “Evaluasi Layanan Taman Bacaan Masyarakat @ Mall: Blok M Mall, Pejaten Village Dan Plaza Semanggi”. Skripsi. Depok: Universitas Indonesia.

Katz, J. E., \& Rice, R. E. 2009. Public Views of Mobile Medical Devices and Services: a US National Survey of Consumer Sentiments Towards RFID Healthcare Technology. International Journal of Medical Informatics, 78: 104-114.

Kementerian Pendidikan dan Kebudayaan. 2012. Petunjuk Tenis Pengajuan dan Pengelolaan Bantuan Taman Bacaan Masyarakat Ruang Publik. Jakarta.

Kementerian Pendidikan dan Kebudayaan. 2015. Petunjuk Teknis Tata Cara Memperoleh Bantuan Sarana Taman Bacaan Masyarakat. Jakarta.

Matthews, J. R. 2009. The Customer-Focused Library: Re-Inventing The Public Library From The Outside-in. California: ABC-CLIO, LLC.

National Library Board. 2015. "Library@Chinatown”. (http://www.nlb.gov.sg/Portals/0/library/documents/librarychinatown\%20-\%20Fact\%20Sheet.pdf, diakses 18 September 2015).

National Library Board. 2015. "Library@Esplanade”. (http://www.nlb.gov.sg/Portals/0/library/documents/libraryesplanade\%20-\%20Fact\%20Sheet.pdf., diakses 18 September 2015).

National Library Board. 2015. "Library@Orchard”. (http://www.nlb.gov.sg/Portals/0/library/gallery/ Orchard/library@orchard\%20-\%20Fact\%20Sheet.pdf., diakses 18 September 2015).

Ngian Lek Choh. 2003. A Totally Do-It-Yourself Library Without a Library Customer Service Desk: the Singapore experience. IFLA Journal, 29: 298-300.

Ngian Lek Choh. 2003. Library 2000 : Its Impact on the National Library of Singapore. IFLA Journal, 23: 
120-123.

Nugroho, F. \& Maureen, I. Y. 2012. Pengelolaan Taman Bacaan Masyarakat Sebagai Penyelenggaran Pendidikan Nonformal di Lingkungan Masyarakat Rusun Bangunrejo Surabaya. Jurnal Mahasiswa Teknologi Pendidikan, 1(2).

Park Sung Jae. 2012. Measuring Public Library Accessibility: a Case Study Using GIS. Library \& Information Science Research, 34:13-21.

Pusat Bahasa Depdiknas. “KBBI Daring”. Jakarta: Departemen Pendidikan Nasional. (http:// badanbahasa.kemdikbud.go.id/kbbi/index.php, diakses 18 September 2015).

Rachmiati, Mia. 2011. TBM@Mall: Gagasan Meningkatkan Minat Baca Masyarakat. Bandung: PP-PNF Regional I Jayagiri.

Redaksi Dunia Perpustakaan. 2010. Kemendiknas Targetkan 561 TBM di 23 Mal. (http:// duniaperpustakaan.com/kemendiknas-targetkan-561-tbm-di-23-mall/, diakses 18 September 2015).

Tan, G., \& Foo, S. 2006. Realising Its Future Through Collaboration With Government, Industry and Community: The Experience of Singapore's National Library Board. Journal of Library and Information Science, 32(1): 34-42. 
